\title{
Da periferia ao centro: cultura e política em tempos pós-modernos
}

CELSO FREDERICO ${ }^{I}$

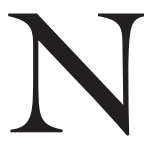
O MÊs de fevereiro de 2013, a revista Carta Capital publicou diversas matérias sobre cultura, mais precisamente sobre o chamado "vazio cultural", que seria, segundo o diagnóstico da revista, a característica definidora do tempo presente.

O fio condutor da reportagem é a relação entre os ciclos da economia brasileira e as manifestações culturais. Três períodos são destacados.

O primeiro, que se inicia com a revolução de 30 , trouxe consigo um conjunto de pensadores com interpretações relevantes sobre o Brasil: Sérgio Buarque de Holanda, Gilberto Freyre, Caio Prado Jr. Na literatura, a centralização federativa provocou uma reação expressa no romance social, revelando autores como Jorge Amado, Raquel de Queiroz e, principalmente, Graciliano Ramos. A música popular revelou Ary Barroso, Dorival Caymmi e tantos outros mestres.

Um segundo ciclo, inicia-se nos anos JK e se estende até 1968. É um momento de modernização capitalista e desenvolvimento industrial, que foi acompanhado, no plano cultural, pelo surgimento do cinema novo, do teatro de Arena e do teatro Oficina, do CPC da UNE, da arquitetura de Oscar Niemeyer, da bossa-nova e dos compositores da MPB (como Chico, Milton, Edu Lobo etc.) e do tropicalismo.

E hoje? Depois de 12 anos da era Lula, as políticas de inclusão social e de incentivo à educação e à cultura, o que se pode dizer? O tom geral da revista é de desânimo: estamos vivendo um vazio cultural. A superestrutura caminha vagarosamente e parece não querer acompanhar o desenvolvimento social...

Essa mesma percepção acompanha muitos estudantes que se voltam para o passado com olhos nostálgicos, deixando transparecer que eles prefeririam ter nascido noutros tempos, quando as coisas importantes aconteciam...

De fato, toda a movimentação cultural da década de 1960 gravitou em torno do público estudantil e da classe média escolarizada. Esse segmento conheceu um vertiginoso crescimento. Marcelo Ridenti (2013) chamou a atenção para esse fato:

Dados do MEC apontam que há hoje cerca de 7 milhões de universitários. O 
acesso ao ensino superior praticamente dobrou em uma década. Em 2000, eram admitidos anualmente 900 mil calouros. Em 2011, quase 1,7 milhão. Dois terços no ensino privado. A título de comparação, tome-se a década das manifestações estudantis. Em 1960, havia 35.909 vagas no ensino superior,

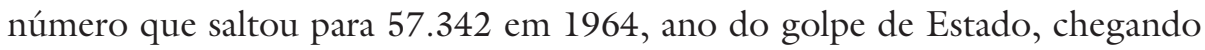
a 89.582 no tempo das revoltas de 1968, a maioria no ensino público. Em termos absolutos, a evolução foi enorme. Não obstante, apenas 15\% dos brasileiros com idade de estar na faculdade cursam o ensino superior.

Dados eloquentes que, contudo, não tiveram reflexos significativos no campo cultural. Mas as manifestações culturais surpreendentemente apareceram na outra ponta: entre os $85 \%$ dos jovens conhecidos como "nem nem" - aqueles que não estão nem na universidade e nem no mercado de trabalho formal.

Esses novos protagonistas habitam um território de localização geográfica imprecisa, que passou a ser designado pela polissêmica palavra periferia. Essa é a novidade que nega o propalado "vazio cultural", diagnóstico que revela uma concepção restrita do que se entende por cultura. ${ }^{1}$

Os bairros populares, situados às margens da cidade, não eram chamados de periferia. O batismo ocorreu inicialmente na sociologia urbana para designar um espaço de carência, marginalidade, violência e segregação. Daí o termo foi adotado pelos movimentos culturais para, em seguida, ser incorporado pelas políticas públicas que visam à inclusão social - inclusão, diga-se, restrita à participação no mercado de bens de consumo. Ultimamente, a eterna sanguessuga, a indústria de entretenimento, passou a enfocar a periferia em filmes, novelas, anúncios publicitários etc.

A publicização do termo periferia deu ensejo, assim, à sua apropriação por diferentes campos discursivos que buscavam, cada qual a seu modo, cristalizar um significado, conferir-lhe um conteúdo. Esse esforço diferenciado de ressignificação da palavra periferia faz lembrar Bakhtin que via no signo linguístico "a arena da luta de classes".

As várias significações possíveis, contudo, passaram a existir graças à explosão cultural iniciada a partir da década de 1990 que deu visibilidade a um processo em curso.

A década de 1980 foi marcada por uma intensa movimentação social. Enquanto o mundo padecia dos efeitos do neoliberalismo e da reestruturação produtiva (desmantelamento dos direitos trabalhistas, crise do sindicalismo etc.), o Brasil atravessava um momento de ascenso do movimento popular, com a formação das centrais operárias, do Movimento Sem-Terra, da legalização dos partidos de esquerda - processo que culminou na Constituinte Cidadã, em 1988.

Nos anos 1990, entretanto, a ofensiva neoliberal fortalecida pela desagregação do bloco comunista chegou finalmente ao Brasil. A crise social e o enfraquecimento do movimento operário foi acompanhado da guinada "pragmática" 
do Partido dos Trabalhadores e da desmobilização das Comunidades Eclesiais de Base. Na cidade de São Paulo, a administração Paulo Maluf, privilegiando o transporte individual e a consequente construção de avenidas e viadutos, deixou a periferia abandonada. A concentração de renda, de um lado, favoreceu o surgimento de condomínios fechados e, de outro, a crescente favelização.

Os resultados sociais logo se fizeram sentir na periferia, retratada pelos jornais como o lugar do tráfico de drogas, da violência policial e da degradação das condições de vida. Mas, foi justamente na década de 1990 que a periferia conheceu uma surpreendente floração cultural.

Uma importante análise foi realizada por Tiarajú Pablo D'Andrea (2013). Morador da periferia e participante ativo de movimentos culturais, realizou uma notável pesquisa em que aliou a sua vivência a uma refinada reflexão sociológica. A resposta à crise social, segundo ele, expressou-se nos diversos movimentos culturais: a literatura marginal, ${ }^{2}$ o teatro, as Comunidades do Samba, os saraus, os cineclubes, as produções audiovisuais e, principalmente, o hip-hop, que tem o rap como expressão musical (além do breaking, na dança, e o grafite, nas artes plásticas). ${ }^{3}$ Em 2007, durante a Semana de Arte Moderna da Periferia, Sérgio Vaz leu um manifesto que afirmava: "a arte que liberta não pode vir da mão que escraviza". ${ }^{4}$

Como consequência da visibilidade adquirida, as organizações não governamentais e as políticas públicas assistencialistas passaram a financiar as atividades culturais, por acreditarem ser essa uma saída de emergência, a possibilidade de escape para manter os jovens longe da criminalidade. ${ }^{5}$ Essa aposta no apaziguamento das contradições sociais contou também com a contribuição de empresas privadas adeptas do "discurso empreendedorista".

A ponta de lança da ofensiva cultural dos anos 1990 foram os Racionais $M C$ 's, o grupo de rap que melhor expressou a vivência da periferia naquele momento, tendo obtido um estrondoso sucesso popular, inteiramente construído às margens da indústria cultural.

Os Racionais, segundo Tiarajú Pablo D'Andrea, conseguiram como ninguém exprimir o surgimento da nova subjetividade do emergente sujeito periférico. A condição compartilhada gerou um forte sentimento de orgulho, acompanhado de uma crítica à sociedade que os condenava à segregação. Trata-se da formação de uma visão do mundo, como diria Lucien Goldmann, que compartilha códigos, valores e que acena para a ação coletiva.

Trilha sonora da periferia, o rap foi o responsável pela "educação sentimental" dos negros pobres, que constituem a grande maioria do sujeito periférico. Mas essa não é uma característica apenas brasileira: em todas as grandes cidades de nosso mundo globalizado o rap se fez presente para manifestar sua crítica agressiva à sociedade. Gênero musical novo (mas que retoma a forma antiquíssima do cantar: o cantochão); baseado no pulso e não na linha melódica e nas possibilidades do campo harmônico (o que dispensa, portanto, uma 
formação musical que vai além da rítmica) - o rap surgiu como a forma musical preferida para a vocalização dos excluídos. O resultado final é a verborragia martelante que fustiga os ouvidos e irrita quem procura na música algum bálsamo para o espírito... ${ }^{6}$

Mas, esta é a forma adequada para o novo gênero. Walter Garcia (2003, p.171), após estudar a batida do violão de João Gilberto como doadora da forma da bossa-nova, voltou-se para o estudo dos Racionais mostrando como a realidade violenta aparece "em cada recurso poético", "através das palavras de rua", de modo que "a técnica de feitura das obras está completamente adequada à profundidade das experiências representadas".

Uma das hipóteses mais interessantes levantadas pela pesquisa de Tiarajú Pablo D'Andrea seria a existência de “afinidades eletivas” entre manifestações aparentemente opostas como o rap, a proliferação de seitas evangélicas, o lulismo e o PCC - todos eles movimentos que explodiram na década de 1990 como resposta a uma situação comum. O elemento unificador seria a existência de uma "gramática moral", de um código de conduta - um "procedimento" - forjado para se sobreviver numa situação agônica comum a todos os sujeitos periféricos.

\section{III}

Se realmente se pode falar numa nova subjetividade, numa "visão do mundo" cuja expressão mais articulada foi oferecida pelos Racionais, deve-se também lembrar que uma identidade também se constitui em oposição a algo. Afinal, quem é o inimigo?

Sobre esse ponto, as opiniões divergem.

Segundo Walter Garcia, a violência é o que estrutura a narrativa dos $R a$ cionais. Permeando as relações sociais, a violência vivida é expressa de modo igualmente agressivo:

essa violência generalizada é resultado do sistema capitalista, responsável pela transformação de tudo (incluindo sentimentos e projetos de vida) e de todos ("preto, branco, polícia, ladrão") em mercadoria (com valor medido em dinheiro); essa universalidade, porém, convive com uma forma de opressão particular, o preconceito e a segregação racial. (ibidem, p.173)

Essa convivência entre o universal e o particular, contudo, tende a trazer para o primeiro plano a segregação racial. Esse é um fato novo na história da periferia, lembrando que após as greves ocorridas em fins dos anos 1970 a sociologia passou a exaltar a "dignidade do trabalho" como elemento orientador da ação operária, bem como chamar a atenção para o teatro operário que acompanhou os movimentos grevistas. ${ }^{7}$ A perspectiva classista, contudo, parece não ter resistido à reestruturação produtiva que trouxe à baila, em tempos pós-modernos, além da questão racial - a maldição de origem de nossa sociedade - também a questão juvenil dos "nem nem":

[...] por conta do desemprego e de uma tendência a fragmentação das categorias do mundo do trabalho, a sociabilidade passa a se dar mais no bairro ou no 
universo urbano (deslocamentos, locais de consumo coletivo, áreas de lazer, etc.) do que propriamente no local de trabalho. As desigualdades territoriais expressariam melhor elementos étnicos e geracionais que tendiam a ser escamoteados na identificação trabalhador, com maiores dificuldades de pensar a questão juvenil e a questão negra. (D’Andrea, 2013, p.154-5)

Resta saber se essa ênfase no particular é uma passagem enriquecedora para o universal e, portanto, o caminho para a emancipação do gênero humano, ou um fechamento, algo semelhante ao "obreirismo" e o "corporativismo" no movimento sindical.

Essa segunda opção é afirmada enfaticamente por Tereza Caldeira (2011, p.301-2):

[...] nos anos 1990 havia se consolidado em São Paulo um novo padrão de segregação espacial baseado na criação de enclaves fortificados e no uso intensivo de sistemas de segurança. Esse é um padrão de segregação cuja lógica é impor separações. Os novos movimentos culturais e artísticos que se consolidaram nos anos 1990 expressam alguns dos paradoxos dessa democracia violenta e dessa cidade segregada. [...] paradoxalmente, eles também recriam alguns dos termos de sua própria segregação ao reinventarem simbolicamente a periferia como um gueto isolado, uma imagem importada do rap norte-americano. Dessa maneira, eles constroem uma postura de autorreclusão similar às práticas de reclusão das classes altas, e seu protesto contra a exclusão acaba contribuindo para a reprodução de espaços segregados e intolerância.

Quanto à intolerância, a autora chama a atenção para o modo preconceituoso como o rap, em geral, e os Racionais, em particular, referem-se à mulher. A "difamação das mulheres", diz, faz parte da tendência a "policiar as fronteiras de uma comunidade que se mantém unida na base da 'atitude' e onde não existe tolerância com as diferenças" (ibidem, p.315). As mulheres, ao contrário dos músicos, procuram ter empregos regulares e, por isso, são vistas como potencialmente “integradas" - um perigo para a coesão da comunidade.

Haveria, assim, uma mudança de postura em relação aos movimentos sociais dos anos 1970 e 1980: estes, tendo como referencial o mundo do trabalho, apresentavam-se como uma "comunidade unida" reivindicando a inclusão na ordem social e a extensão dos direitos sociais. Já o hip-hop, diz a autora, colocou-se fora da esfera política adotando, assim, uma posição de enclausuramento cujo único direito que imaginam ter é o direito de liberdade de expressão. Por isso, conclui Tereza Caldeira, existem

limites para o tipo de comunidade e políticas que eles possam criar. Eles pensam a periferia como um mundo a parte, algo similar ao gueto norte-americano, um imaginário que nunca foi utilizado antes no Brasil para pensar as periferias. Além disso, a democracia não é uma palavra de seu léxico; é de fato uma noção que pertence ao outro lado, ao lado da sociedade branca e rica. Suas evocações de justiça não são necessariamente feitas em termos de cidadania e estado de direito - como era a dos movimentos sociais (e, nesse sentido, seus clamores por justiça têm, por vezes, uma preocupante similaridade com o modo como 
os comandos do crime organizado usam os mesmos preceitos). É uma ordem moralista, onde não existe lugar para a diferença. (ibidem, p.318)

Essas duas posições antagônicas, que oscilam da afirmação do caráter revolucionário do rap ao particularismo segregacionista, contêm, cada qual a seu modo, elementos verdadeiros coexistindo no interior de uma argumentação um tanto peremptória.

Sem muita dificuldade, percebe-se o ponto de vista, digamos assim, “democrático" de Tereza Caldeira, que gostaria de ver a coexistência pacífica dos opostos numa sociedade multiculturalista tolerante. Por outro lado, sua crítica certeira ao enclausuramento aponta para um limite da consciência possível dos sujeitos periféricos.

Uma terceira posição é defendida por Pablo Nabarrete Bastos. Em sua pesquisa teve o cuidado de discernir três tendências atuantes no hip-hop. A primeira delas trabalha com a centralidade da questão racial; a segunda dedica-se à crítica do capitalismo; a terceira centra-se na questão cultural e na formação dos jovens para a cidadania. Mas, mesmo o segmento anticapitalista repete a visão dualista restrita ao imediato, como se pode perceber na declaração de um dos integrantes do grupo de rap Sádicos Contra o Sistema: "o sistema pra nós era a grosso modo: playboy, polícia, governo”. A referência ao governo, contudo, não impede que muitos grupos atuem em parceria com os departamentos culturais de prefeituras petistas. ${ }^{8}$

Se o envolvimento com prefeituras e as ONG traz problemas para movimentos que pretendem ser anticapitalistas, a colonização pelo consumo é uma ameaça ainda mais terrível. A análise excessivamente otimista de Tiarajú Pablo D'Andrea não deixa de assinalar, a contragosto, as tentações do consumismo envolvendo as últimas produções dos Racionais, bem como de lembrar a participação do grupo ao lado de Jorge BenJor em uma campanha da Nike. Não se trata de julgamento moral, pois a questão de fundo é outra e nos remete aos impasses do dualismo afirmado pela cultura da periferia. Afinal, a parte pode permanecer isolada do todo? É evidente que a presença da "sociedade inclusiva", para usarmos o jargão sociológico, acaba "contaminando" a todos.

A cultura das classes populares não é em si mesma progressista e nem sempre é original e de boa qualidade. Gramsci, quando falou do folclore, usou a expressão "fragmentos indigestos" para assinalar a coexistência de conteúdos progressistas e reacionários. De modo assemelhado, encontramos na periferia tanto manifestações regressivas como o recente fenômeno do "funk da ostentação", que enaltece as grifes e o dinheiro, como também aquelas que se pretendem anticapitalistas.

Sobre o "funk da ostentação", que replica a ideologia dominante, é ilustrativa a reportagem publicada pela revista Época:

Vida é ter um Hyundai e uma Hornet/10 mil para gastar, Rolex e Juliet, canta o paulista MC Danado no funk “Top do momento”. Para quem não entendeu, 
ele fala, na ordem, de um carro, uma moto, dinheiro, um relógio e um par de óculos - um refrão avaliado em R 400 mil. Na plateia do show da Zona Leste, região que concentra bairros populares de São Paulo, os versos são repetidos aos berros pelas quase 1.000 pessoas presentes. [...]. O público de sexta-feira é jovem, etnicamente diverso e poderia ser descrito em três palavras: "classe $\mathrm{C}$ emergente".?

O MC Lon resumiu a ideologia do movimento: "A gente quer ostentar cada vez mais. Queremos chegar onde os gringos do rap chegaram. Nóis canta ostentação porque pode. É como se fosse a celebração de uma vitória” (Lima, 2013).

André Singer (2013), comentando o fenômeno, observou "a autenticidade da manifestação. Tal como no rap, são vozes da comunidade falando para a comunidade". Mas, constata, "os valores expressos são justamente os que emanam da publicidade". Por isso, conclui tratar-se de "uma extraordinária vitória do capitalismo" (ibidem).

Essa “invasão" da ideologia dominante na periferia exige a superação da concepção dualista que separa a sociedade em brancos e negros; centro e periferia; manos e playboys.

\section{IV}

O fechamento em torno de uma imaginária “comunidade unida” que afirma o dissenso como princípio opõe-se, evidentemente, a qualquer possibilidade de integração.

Mas, o que significa, exatamente, integração? Integração é aceitação conformista da sociedade que promove a ascensão social da "classe C emergente" através do consumo? É possível uma integração crítica?

A questão me faz lembrar, em primeiro lugar, do método Paulo Freire. A integração do analfabeto na sociedade letrada significava, no caso, tomada de consciência e não um mero passaporte para o mundo letrado.

Lembro também de um amigo psicanalista protestando contra aqueles que dizem que a psicanálise procura integrar o neurótico à sociedade neurótica. A sociedade, argumentava, é contraditória: integrar significa dar consciência e permitir que o indivíduo escolha entre valores alternativos.

Considerando a ambiguidade do termo integração, podemos desdobrar a questão e perguntar: o que se deve entender por integração cultural?

Hoje, em tempos de multiculturalismo, há uma tendência ingênua de valorizar acriticamente o conteúdo revolucionário da efervescência cultural na periferia. Os seus protagonistas, por sua vez, tendem a afirmar a sua "pureza", evitando a "contaminação": com isso, pensam em manter a "autenticidade" da cultura da periferia opondo-se radicalmente à cultura praticada no "centro". $\mathrm{O}$ limite dessa visão consiste em manter o isolamento cultural através da criação de "parques temáticos", de segmentos estanques que afirmam o seu particularismo e negam o diálogo. Negam, portanto, a própria possibilidade de se desenvolverem, de superarem os seus limites com sua insistência em permanecer 
no gueto. Essa posição dual exaspera o antagonismo, mas não aponta para a superação - seja pelo aprofundamento da democracia, seja pela revolução social. Ela, portanto, permanece, digamos assim, numa "negação negativa” incapaz de transcender os limites em que se enclausurou, incapaz de fornecer um projeto universalizante para a transformação revolucionária da sociedade mercantil.

Um exemplo expressivo desse particularismo hostil ao diálogo foi patrocinado recentemente por seiscentos estudantes de escolas públicas da periferia de Campinas. Esses estudantes, entre dez e doze anos de idade, foram contemplados com o programa "Ouvir para crescer", dedicado à iniciação musical. Num dos teatros municipais, na Vila Industrial, atores apresentaram as principais características da linguagem musical. Em seguida, o grande pianista André Mehmari aproximou-se do piano para tocar uma música de Ernesto Nazareth. É o crítico literário e músico José Miguel Wisnik quem informa: “ao começar uma explicação sobre a sua participação, e mesmo antes de tocar, começou a receber vaias e xingamentos pesados, intensivos, que se multiplicaram e continuaram ao longo de toda a apresentação". A presença "aristocrática" do piano e o estranhamento de classe social, certamente são fatores que, ao lado da crise da instituição escolar, contribuíram para a agressividade do público. O crítico concluiu que a reação dos estudantes "faz parte de uma rede de identidades que se constituem precariamente sobre a relação rivalitária de indivíduos e grupos cuja afirmação de existência depende da negação frontal do outro" (Wisnik, 2013).

Esse exemplo não é um caso isolado. Recentemente, minha filha participou da tentativa de organizar um evento cultural na PUC-SP. Na reunião com os colegas, alguém sugeriu chamar Chico Buarque de Holanda. Um dos presentes, aluno beneficiado pela inclusão na universidade pelo sistema de cotas, protestou: "Chico Buarque é um playboyzinho, o pessoal não entende as coisas dele. Temos que chamar alguém que fale a língua da periferia”.

Esse fechamento pode ainda ser visto na experiência vivida pelo rapper de São Bernardo, Walter Limonada, quando se dirigia à biblioteca para devolver alguns livros e encontrou um amigo que o repreendeu: "esse negócio de livro não é postura de rapper”. Pablo Nabarrete Bastos, que reproduziu o encontro, acrescentou:

Eu já presenciei jovens do Hip-Hop criticando, até mesmo os seus pares, por querer colocar em debate e palestras alguma referência da ciência clássica, como Marx, por achar que era uma atitude pernóstica, ou na linguagem deles: "O Jão tava querendo se crescer pra cima dos mano, não vem querer falar bonito aqui não que aqui é quebrada e o bicho pega". (Bastos, 2008, p.319)

Nos três exemplos, a mesma intolerância de quem quer afirmar agressivamente o seu particularismo e se recusa a ouvir quem fala uma linguagem "diferente" - uma linguagem de classe média, branca, culta...

A integração pela cultura, sem dúvida, melhora a autoestima de setores marginalizados, mas também pode colaborar para acentuar os irredutíveis parti- 
cularismos. A integração crítica e revolucionária, contudo, necessita do esforço universalizante da educação, tanto a escolar como a política. E a cultura não pode ser o substituto da educação.

No caso dos sujeitos periféricos, a visão dualista que não se transcende escolhe como inimigo o que é dado imediatamente na vivência cotidiana: a polícia, o racismo, o playboy, os políticos. Mas aqui podemos apontar, como já o fez Tereza Caldeira, para uma impertinente "afinidade eletiva" com a outra parte da sociedade segmentada - aquela que vive em condomínios fechados. Esse setor também participou da glorificação da cultura, no momento em que se configurava a passagem da mercantilização da cultura, tal como descrita pela teoria adorniana da indústria cultural, para a culturalização da economia. Autores como Debord já haviam afirmado que a cultura seria a "mercadoria vedete" da sociedade do espetáculo. Mais recentemente, Jameson escreveu sobre a "dominante cultural" no capitalismo tardio.

Na passagem para o século XXI, começou-se a falar em "economia criativa” para designar um novo e rentável ramo dos negócios. Em 2008, esse ramo era responsável por $7 \%$ do PIB mundial. Por conta disso, a Unesco, que até então cuidava da cultura, viu suas atribuições se encolherem em proveito da Organização Mundial do Comércio e da União Internacional de Comunicação. Do mesmo modo, a economia da cultura passou a integrar as políticas públicas. Um documento do MEC, durante o governo FHC, informava que "cultura é um bom negócio”.

Como negócio, a alta cultura passou a seguir a lógica especulativa do capital financeiro. Ela deixou de ser um bem público e passou a ser um ativo financeiro à espera de valorização. Os bancos e os especuladores do mercado de capitais rapidamente converteram-se aos encantos da obra de arte, atraídos pelo seu valor de troca em permanente valorização e não pelo seu valor de uso.

Juntando as pontas, pode-se ver como a representação caótica da realidade provocada pelo fetichismo mercantil se expressa nos contrários: a permanência no imediato, no visível (polícia, playboy), entre os sujeitos periféricos, e a adoração da aparência sensível (o valor de troca), pela burguesia dos condomínios fechados em seu recente entusiasmo pela cultura.

\section{V}

Entre os dois extremos encontra-se a classe média branca - aquela que saiu às ruas em junho de 2013. Como a palavra periferia, classe média é uma expressão ambígua, sujeita às interpretações mais diferenciadas.

As pesquisas de André Singer (2012) sobre o lulismo e as de Márcio Pochmann (2012) sobre a classe média são referências básicas para se entender o tempo presente. Elas confluem no diagnóstico: a partir de 2005 a classe média abandonou o lulismo e aderiu majoritariamente às posições de direita. Essa retirada efetivou-se como resposta à nova base social que passou a sustentar o lulismo - o subproletariado beneficiado pelas políticas públicas de inclusão social. Tais 
políticas, de viés paternalista, que visam à integração por meio da participação nos bens de consumo, não atacam a exploração capitalista, mas apenas procuram diminuir os seus efeitos. De qualquer modo, esse enorme contingente social passou a garantir as vitórias eleitorais do PT. Sem mobilização e conscientização, o lulismo consolidou uma hegemonia passiva em que o centro da ação deixou de ser as relações de produção capitalistas, passando a concentrar-se no combate à pobreza.

Nesse contexto, a classe média abandonou o lulismo, migrando para a direita. Um pequeno segmento, contudo, deslocou-se para os partidos de esquerda. Surpreendentemente, essas duas vertentes estiveram juntas nas manifestações de junho. A crise de representação dos partidos e sindicatos abriu o caminho para os protestos. ${ }^{10}$

Todos queriam ser protagonistas; ninguém mais queria ser "representado". Sem a presença de partidos - que existem para universalizar as reivindicações - tais manifestações correm o risco de se dispersar num conjunto infinito de reivindicações particularistas e, o que é pior, de serem pautadas pelo novo partido da sociedade do espetáculo: o "partido da mídia". As manifestações, organizada pelo Movimento Passe Livre, por estudantes secundaristas e pelos movimentos de moradia da zona sul, tiveram como canal de divulgação as redes sociais. Rapidamente, o movimento ganhou adesão e os sujeitos periféricos saíram de seus guetos, o que conferiu à luta traços de uma revolta popular. Nesse momento, a cobertura ao vivo realizada pela televisão passou a convocar abertamente o telespectador à participação, ao mesmo tempo em que procurava imprimir um determinado sentido aos acontecimentos. Como consequência, os links que comentavam os fatos, retirados da mídia impressa, tiveram uma influência direta sobre a opinião pública. A revolta contra o aumento da passagem de ônibus, ao invés de traduzir-se na luta pela estatização das companhias de transporte público, desviou-se para uma pluralidade de reivindicações menores.

Tais reivindicações foram levantadas por personagens neófitos em política que inesperadamente entraram em cena: os "coxinhas". Enrolados na bandeira do Brasil, eles portavam cartazes com protestos contra a corrupção - a antiga bandeira da moralidade que a direita, desde os tempos de Getúlio e, depois, de Goulart, sempre levantou contra os governos progressistas. Essa multidão de indivíduos solitários, moldados ideologicamente por décadas de hegemonia do neoliberalismo, fazia, assim, a sua estreia na vida pública.

"Paradoxo das consequências", diria Max Weber: um movimento concebido numa óptica anticapitalista nas redes sociais seguiu caminhos inesperados e contrários à orientação inicial. Esse fenômeno obriga à reflexão sobre a internet, distante das tradicionais interpretações apocalípticas ou integradas. As possibilidades emancipatórias da internet convivem com sua colonização pelas atividades comerciais, pela presença agressiva de internautas profissionais a serviço de partidos, empresas etc., e, hoje sabemos, por uma implacável vigilância por parte dos 
Estados Unidos. O ciberativismo, por sua vez, é tanto uma ferramenta para a ação coletiva como um canal para o individualismo irresponsável. É fácil clicar um botão e aprovar ou reprovar algo. Veja-se, por exemplo, a luta pela legalização da maconha: milhares de internautas se comprometeram a participar de uma manifestação da PUC-SP, mas na hora $\mathrm{H}$ apareceram somente alguns gatos pingados...

O Movimento Passe Livre, após promover algumas manifestações numericamente inexpressivas, foi surpreendido em junho com a multidão que foi às ruas. Cabe lembrar que esse movimento é, de certo modo, herdeiro de 68, especialmente do espírito libertário que propaga a horizontalidade e critica as organizações políticas tradicionais. "Centralismo democrático" e "espírito de partido" são considerados, com alguma razão, princípios burocráticos e autoritários. No Brasil, tal espírito orientou, por exemplo, a ação de Marighela e da ALN. A ruptura com o centralismo estimulava a ação autônoma de pequenos grupos não subordinados a nenhum comando. Uma das formas de ação era a "propaganda armada": um grupo invadia uma fábrica, distribuía panfletos e exibia orgulhosamente as armas para os trabalhadores, acreditando, com isso, estar ensinando o caminho da revolução - como se a imagem pudesse substituir o trabalho político de convencimento e conscientização.

O autonomismo contemporâneo e a espetacularização da política como antídoto à burocracia apoia-se em autores como Toni Negri, Cornelius Castoriadis, nos teóricos da autogestão e no neoanarquismo. Essa orientação insere-se no espírito de 68 - em especial, naquele caldo de cultura que direcionou diversas correntes de pensamento, como a antipsiquiatria, o multiculturalismo, algumas tendências pedagógicas etc., todas elas fazendo da horizontalidade a expressão por excelência da democracia.

Uma estranha dialética entre o individual e o coletivo se manifestou nos protestos de junho. Os indivíduos autônomos e anônimos foram às ruas e se encontraram com seus pares. Formou-se, assim, para usarmos uma expressão de Hegel, uma "multidão atomística de indivíduos juntos". As máscaras do filme $V$ de Vingança, usadas nas passeatas, encobriram os rostos, mas não aboliram as individualidades misturadas no coletivo, um coletivo impessoal, uma multidão.

"A multidão é uma multiplicidade de singularidades que não pode encontrar unidade representativa em nenhum sentido", segundo pensa Antonio Negri (2003, p.43). Essas singularidades em comum seriam um novo sujeito destinado a ocupar o lugar da antiga classe operária, classe em que as individualidades permaneciam atreladas à idêntica posição no interior das relações de produção. ${ }^{11}$ Nos tempos pós-modernos de hegemonia do trabalho imaterial teria surgido uma alternativa à antiga dialética do singular e do geral, do uno e dos múltiplos. Hegel, astuciosamente, colocara, entre o universal abstrato e as singularidades soltas, a categoria mediadora da particularidade. A ação direta e o culto do autonomismo, contudo, se revoltam contra a mediação - seja essa representada por partidos ou sindicatos, instâncias consideradas "externas" ao 
soberano movimento que, em sua imanência, constitui o novo sujeito em luta pela "democracia absoluta" (conceito que remete a Espinosa). A revolta produz, assim, auto-organização, antipoder, resistência, poder constituinte.

A multidão desponta como uma classe perigosa e "demoníaca". Negri (2005) reporta-se ao Novo Testamento, àquela parábola em que Jesus foi exorcizar um homem possuído pelo demônio e, ao perguntar seu nome, obteve como resposta: "Legião é o meu nome, pois somos muitos". Em seguida comenta: "Um dos aspectos curiosos e perturbadores dessa parábola é a confusão gramatical de sujeitos singular e plural. O demoníaco é ao mesmo tempo 'eu' e 'nós'. Existe aí uma multidão" (ibidem, p.186).

O "demoníaco" deu seu ares da graça nas manifestações de junho, quando depredações, vandalismo e roubo de lojas aproximaram grupos punks, Black Blocs, policiais infiltrados, ladrões e adeptos da ação direta. Não estamos mais diante da "luta dos contrários", mas do culto pós-moderno da transgressão, dos impulsos imediatistas contra a "normatividade".

Como consequência, o movimento foi progressivamente se esvaziando. Seus promotores iniciais, pressionados de um lado pela intervenção da mídia querendo pautar os rumos e, de outro, pela ação de provocadores de todo tipo, recuaram temerosos.

Uma das análises mais brilhantes dessas manifestações foi feita por Aton Fon Filho, que apontou a aproximação das duas vertentes políticas que foram às ruas, direita e esquerda: "De uma classe média desorganizada, mas sob a influência/hegemonia de linhas políticas de direita que, em muitos casos, incorporou palavras de ordem da oposição de esquerda, o que se tem nas ruas é um amálgama mal construído de boas intenções e generalidades" (Fon Filho, s. d., p.7).

A questão da cultura mais uma vez se fez presente na estetização da política promovida principalmente pelos "coxinhas" e pelos Black Blocs. Com o mesmo espírito manifestaram-se os demais participantes, substituindo a questão social por uma agenda ancorada em abstratos valores éticos, na defesa dos direitos humanos (moradia, trabalho, saúde, transporte etc.) e, em menor escala, nos direitos identitários (a luta contra a discriminação de raça, gênero e orientação sexual) e na legalização do aborto e da maconha. A luta deixou de ser pelos vinte centavos no preço das passagens para se tornar uma luta por direitos conduzida pela lógica do espetáculo:

não sendo uma força organizada cada um ficava responsável por definir o que levava à manifestação. E cada um sabia que iria possivelmente ser filmado por um dentre os milhares de celulares e câmeras nas ruas. E iria para a internet, no facebook ou num blog, ou num site ou no instagram. E poderia ir para os jornais ou para os sites dos jornais. E para a televisão. Cada um que cuidasse, portanto, do modo como iria aparecer, como iria ser espetáculo. (ibidem, p.8)

Nos desdobramentos que se seguiram às primeiras manifestações, a palavra final foi dada pelos Black Blocs. Esse grupo de extração anarquista propõe a ação 
direta contra os símbolos materiais do capitalismo. Suas manifestações violentas são dirigidas para a destruição da propriedade privada e não para a sua socialização. Os símbolos mais visíveis do capitalismo se tornaram, portanto, o alvo predileto de suas ações.

Uma reportagem da revista Carta Capital explicou a forma de atuação dessa corrente: "O surgimento de um bloco não é centralizado nem permanente. É o encontro de indivíduos com propósitos similares, mas nunca coibidos pela coletividade". Tais propósitos concentram-se na violência como ação direta, o que confere à política um "caráter mais estético, espetacular, de intervenção urbana" (Locatelli; Viera, 2013, p.24-5). Um ativista entrevistado pela revista declarou: "Nossa sociedade vive permeada por símbolos. Participar de um Black Blocs é fazer uso deles para quebrar preconceitos, não só do alvo atacado, mas da ideia de vandalismo. Não há violência $(s i c)$. Há performance”. Especialistas na área de políticas culturais afirmam que o Black Blocs "é mais do que um movimento, ele é uma estética" (Bruno Torturra) e que o seu ativismo opera "na interface da política com a arte" (Pablo Ortellado).

A estetização da política segue, assim, em direção contrária à politização da arte defendida pelo rap. Os leitores de Walter Benjamin devem lembrar que a primeira posição era originalmente defendida pelo fascismo e estranhar sua migração para o neoanarquismo...

A política como espetáculo midiático, como "evento", tem a sua face carnavalesca com os "coxinhas" e "demoníaca" com os Black Blocs.

Tal política leva à fragmentação e ao individualismo. Comportamento típico da pequena-burguesia, e incentivado ao máximo pelo neoliberalismo, o individualismo tem como um dos seus vetores as "políticas de identidade" centradas nas "irredutíveis" diferenças. Mas estas são proliferantes, como atesta, entre outros, o movimento gay - a afirmação identitária desse movimento seguiu a lógica da contínua divisão expressa nas seguidas siglas que procuram nomear esse contingente social: GLS, GLBS, GLBT, GLBTS, GLBTTIS etc. Esse movimento progressivo, em que o uno se dispersa no mal-infinito dos múltiplos, foi chamado por Antônio Flávio Pierucci de "ciladas da diferença" (Pierucci, 2000). De qualquer modo, continuamos no gueto, destino comum dos manos em sua identidade territorial, das diferenças proliferantes e dos protestos segmentados.

$\mathrm{Na}$ história das lutas sociais, a reinvindicação da diferença sempre foi uma bandeira conservadora levantada contra a defesa socialista da igualdade e a ampliação dos direitos sociais. A esquerda, contrariamente, levantava palavras de ordem universalizantes, variando do "internacionalismo proletário" ao "nacionalismo". Em tempos pós-modernos, a bandeira da diferença mudou de lado e a esquerda empenhou-se em dar vida ao que Derrida chamava de "o jogo infinito das diferenças".

Nas manifestações de junho de 2013, a reivindicação original do "passe livre" nos transportes, reivindicação anticapitalista que entendia o transporte 
como um direito social, e não uma mercadoria, foi passada para trás pelas palavras de ordem aleatórias de uma multidão atomizada formada, sobretudo, por indivíduos das classes médias. A presença desses novos atores trouxe às ruas as reivindicações particularistas e festivas da "vontade de todos" - o somatório dos interesses particulares que não deve ser confundido com a rousseauniana "vontade geral". Essa substituição de uma pauta unificada por reivindicações esparsas impediu que se atacasse a essência dos problemas, ficando-se, por assim dizer, na periferia, ou melhor, em suas manifestações visíveis, cultivando um fazer político performático bem ao gosto do pós-modernismo, que, no lugar da palavra, da argumentação persuasiva, prefere o culto da imagem.

Não foi por mero acaso que a palavra de ordem gritada nas ruas - "vem pra rua, vem!" - tenha replicado o slogan da propaganda de uma marca de carros que então era veiculada exaustivamente na televisão. Apropriação crítica ou adesão irrefletida à linguagem da mercadoria?

Seja como for, ficamos enredados no campo dominado pela mídia, que não só reflete, mas, sobretudo, impõe pela manipulação das imagens o simulacro no lugar do real, visando com isso pautar a conduta dos indivíduos tanto na esfera cultural como na politica. Estudando a questão urbana, Otília Arantes (Arantes, 2000, p.22), reportando-se a David Harvey (1992, p.88-92), chamou a atenção para a mudança operada: “a substituição pós-moderna do espetáculo como forma de resistência ou de festa popular revolucionária pelo espetáculo como forma de controle social".

O que se pode observar em todos os setores é o triunfo da lógica do capital, do fetichismo da mercadoria e sua contrapartida: a estetização da política. O culto das grifes no funk da ostentação ou a crítica abstrata ao "sistema", na visão dualista dos rappers - ambos prisioneiros do imediato; o encantamento súbito de uma burguesia financeirizada pelo valor de troca da obra de arte, ou a atuação performática dos Black Blocs que investem contra os odiosos "símbolos visíveis" do capitalismo - complemento perfeito para as declarações de amor da burguesia ao invólucro da mercadoria, pelas grifes, pela marca, pelo valor de troca. Assim, consuma-se o espetáculo, a manifestação sensível da representação caótica de um mundo que parece governado pelo movimento automático das mercadorias.

Cabe lembrar, a propósito, a contribuição pioneira de Guy Debord que, em sua crítica ao mundo mercantil, entendia o espetáculo como sendo o "monopólio da aparência” e, contra ele, reivindicava não a contestação midiática do espetáculo, mas a "linguagem da contradição".

\section{Referências}

ARANTES, O. Uma estratégia fatal. A cultura nas novas gestões urbanas. In: ARANTES, O. et al. A cidade do pensamento único. Desmanchando consensos. Petrópolis: Vozes, 2000. 
ARANTES, P. E. Esquerda e direita no espelho das ONG's. In: Zero à esquerda. São Paulo: Conrad Livros, 2004.

BARBOSA, B. Forte, ativismo digital incomoda mídia, mas sofre ameaças e riscos. $R e^{-}$ vista ADUSP, São Paulo, maio de 2013, p.75.

BASTOS, P. N. Ecos de espelho. Movimento Hip-Hop no ABC paulista: sociabilidade, intervenção e mediações sociais, culturais, raciais, comunicacionais e políticas. 2008. Dissertação (Mestrado) - Escola de Comunicação e Artes, Universidade de São Paulo. São Paulo, 2008.

BOSI, A. Cultura brasileira e culturas brasileiras. In: Dialética da colonização. São Paulo: Cia. das Letras, 1994.

CALDEIRA, T. P. do R. O rap e a cidade. In: KOWARICK, L.; MARQUES, E. (Org.) São Paulo: novos percursos e atores. Sociedade, cultura e política. São Paulo: Editora 34, 2011. p.301/2.

D'ANDREA, T. P. A formação dos sujeitos periféricos: cultura e política na periferia de São Paulo. São Paulo: Programa de Pós-Graduação em Sociologia, USP, 2013.

FON FILHO, A. A direita sai de casa pela porta da esquerda. Disponível em: $<$ http//:viomundo.com>.

GARCIA, W. Ouvindo Racionais MC’S. Tereza, São Paulo, n.4/5, p.171, 2003.

HARVEY, D. A condição pós-moderna. São Paulo: Loyola, 1992.

LIMA, P. Morrer de inveja. Istoé, n.37, julho 2013, p.54.

LOCATELLI, P.; VIERA, W. O Black Bloc está na rua. Carta Capital, São Paulo, 21 ago. 2013, p.24-25.

NASCIMENTO, E. P. do. Literatura marginal: os escritos da periferia entram em cena. São Paulo: Universidade de São Paulo, Programa de Pós-Graduação em Antropologia Social, 2006.

NEGRI, A. 5 lições sobre Império. Rio de Janeiro: DP\&A, 2003.

NEGRI, A.; HARDT, M. Multidão. Rio de Janeiro: Record, 2005.

PIERUCCI, A. F. Ciladas da diferença. São Paulo: Editora 34, 2000.

POCHMANN, M. Nova classe média? São Paulo: Boitempo, 2012.

RIDENTI, M. Que juventude é essa? Folha de S.Paulo, 23 jun. 2013.

SINGER, A. Os sentidos do lulismo. São Paulo: Cia. das Letras, 2012.

Ostentação. Folha de S.Paulo, 16 fev. 2013.

TOMMASI, L. de. Culturas de periferia: entre o mercado, os dispositivos de gestão e o agir político. Política \& Sociedade, São Paulo, v.2, n.23, 2013.

URBINATTI, T. Peões em cena. Grupo de teatro Forja. São Paulo: Hucitec, 2011.

WISNIK, J. M. Não ouvir. O Globo, 25 maio 2013.

\section{Notas}

I Para uma visão ampliada das várias manifestações culturais, ver Bosi (1994). 
2 Veja-se a respeito, Nascimento (2006).

3 Cf. A pesquisa em andamento de Lívia de Tommasi (2013) nas cidades de São Paulo, Rio de Janeiro e Recife, cujos primeiros resultados foram apresentados no ensaio "Culturas de periferia: entre o mercado, os dispositivos de gestão e o agir político".

4 O manifesto pode ser lido/visto no You Tube.

5 Sobre a ação das ONG, ver Arantes (2004).

6 Retomando observações de José Miguel Wisnik sobre a função do refrão na música popular - e o rap raramente tem refrão - Tiarajú P. D'Andrea (2013, p.250) escreveu: "Música sem refrão não canaliza tensões. O refrão é o momento da canção onde as partes encontram o todo. [...]. O refrão é, textualmente, a síntese das particularidades expostas nas estrofes. Por isso mesmo, o refrão é sempre onde entram as principais ideias da canção. $\mathrm{O}$ refrão anuncia o que as estrofes irão dirimir, investigar, exemplificar. O refrão é a síntese. [...] o refrão é o alívio das tensões geradas pelas estrofes, no contínuo musicológico tensão/distensão, assim como nossa respiração". Já o rap, “ao não ter refrão, é pura tensão. Tensão sem distensão. Tensão que não se resolve. Incômodo que não se acomoda. Escutar um rap é passar 10 minutos com a respiração suspensa. Não há refrão, não há repouso". Esta forma musical, conclui, é “a materialização musical da expressão 'correria'. Quem está na correria na vida real não tem direito ao repouso. O próprio fraseado longo, linear e ininterrupto do rap, que não deixa espaço para a respiração, é outro indicativo de ser a expressão musical de indivíduos sem possibilidade de descanso".

7 Veja-se, a respeito do teatro, Urbinatti (2011).

8 Pablo Nabarrete Bastos, "Faces do espelho. Processos de construção de sentidos sobre o movimento Hip Hop do ABC paulista”, ms., s.d., p.14.

9 “O funk de ostentação em São Paulo”, Época, 8 set. 2012.

10 A crise de representação foi vivida de formas opostas. Os estudantes foram às ruas, mas sem a presença da UNE e dos diretórios acadêmicos; pouco depois, a burocracia sindical organizou uma patética manifestação, sem a presença da base operária.

11 A lógica do ativismo digital é outra: "não é mais "proletários de todo o mundo, uni-vos!”. É “hackers, dispersem-se, atuem com autonomia, pelo mundo!”. É a individualidade colaborativa", segundo a opinião de Sérgio Abreu num simpósio promovido pela USP (cf. Barbosa, 2013, p.75).

RESUMO - As relações entre cultura e política ganharam novos contornos no Brasil a partir da década de 1990. A explosão cultural da periferia - tendo à frente o rap expressou-se numa lógica dualista que dividia a sociedade em brancos e negros, centro e periferia, "manos" e "playboys". Essa visão dualista, por sua vez, reflete uma forma de pensar prisioneira do imediato - no caso, a recusa abstrata do "sistema". O mesmo procedimento pode ser visto na classe média que foi às ruas nas jornadas de junho, em 2013. Conduzida pela lógica do espetáculo e manipulada pela mídia, as jornadas também expressaram, na outra ponta da sociedade, uma estetização da política que reproduzia, a seu modo, a permanência no visível, no imediato.

PALAVRAS-CHAVE: Cultura, Periferia, Rap, Jornadas de junho, Mídia. 
ABSTRACT - The relationships between culture and politics have gained new contours in Brazil since the 1990s. The cultural explosion of the urban periphery - with rap in the forefront - expressed itself in a dualistic logic that split society into blacks and whites, wealthier city centers and the poorer periphery, the "bros" and the "playboys." This dualistic view, in turn, reflects a manner of thinking shackled to the immediate present in this case, the abstract refusal of the "establishment". The same modus operandi could be seen in the middle class that took to the streets in the so-called June Days of 2013. Driven by the logic of the spectacle and manipulated by the media, the June Days also expressed, in the other edge of society, an aestheticization of politics that reenacted, in its own way, its persistence in the visible, immediate present.

KEYWORDS: Culture, Urban periphery, Rap, June Days, Media.

Celso Frederico é professor da Escola de Comunicações e Artes da USP e autor, entre outros livros, de Sociologia da cultura. Lucien Goldmann e os debates do século XX (Cortez: 2006) e A arte no mundo dos homens. O itinerário de Lukács (Expressão Popular: 2013). @-celsof@usp.br

Recebido em 23.9.2013 e aceito 15.10.2103.

${ }^{\text {I }}$ Escola de Comunicação e Artes, Departamento de Comunicações e Artes, Universidade de São Paulo, São Paulo/SP, Brazil. 
